\title{
Quality characteristics of beef sausage containing varying levels of ginger (Zingiber
} officinale) powder

${ }^{1}$ Sanwo, K. A., ${ }^{1}$ Olowolafe, O. A., ${ }^{1}$ Iposu, S. O., *Oso, A. O., *Sobayo, R. A., ${ }^{1}$ Ekunseitan, D. A., ${ }^{1}$ Adeyemi, O. A., ${ }^{1}$ Adegoke, A.V., ${ }^{1}$ Adegbite, J. A. and ${ }^{1}$ Abiola, S. S.

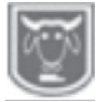

${ }^{\prime}$ Department of Animal Production and Health

*Department of Animal Nutrition

Abstract Federal University of Agriculture, PMB 2240 Abeokuta, Nigeria

Quality of beef sausage with varying levels of ginger powder as seasoning was investigated. Batch 1 was the Control (0\% Ginger powder), Batch 2 had 25\% of the seasoning as Ginger powder, Batch 3 had 50\% of the seasoning as Ginger powder of total seasoning), Batch 4 had 75\% of the seasoning as Ginger powder and Batch 5 had 100\% of the seasoning as Ginger. Parameters measured were all subjected to one-way analysis of variance. Results obtained were significantly $(P<0.05)$ different. For cooking and refrigeration weight losses, batch 1 (0\% ginger powder)) had the lowest percentage cooking weight loss of $9.01 \%$ while batch 2 (25\% ginger powder) had the lowest percentage refrigeration weight loss of $0.73 \%$. Sensory evaluation showed that meaty flavour in batch 1 was highest (6.50) compared to other batches. Crude protein was highest in batch 5 (100\% Ginger powder) with a value of $26.66 \%$ and lowest for batch 1 (0\% Ginger powder) with $18.40 \%$. Up to 100\% ginger inclusion improved refrigeration stability and protein content of fresh beef sausages.

Keywords: Beef Sausage, Zingiber officinale

\section{Introduction}

Sausages can be defined as products in which fresh comminuted meats are modified by various processing methods to yield desirable organoleptic and keeping properties. Sausages are comminuted (ground seasoned meats, stuffed or unstuffed into casing. Merinoff, (2007), also defined sausages as a food made from ground meat, with back fat, salt, herb, and spices. Different spices and herbs have been added to various food products for centuries, mainly to contribute to the characteristic flavour of the end product. Several spices are used for the production of sausages in various concentrations, depending on the type of sausage. The end product in sausage production is greatly influenced by the spices added. Furthermore, some spices- for example ginger contains [6]-Gingerol, a powerful anti-oxidant that can extend the shelf life of dry-fermented sausages. Indeed, the oxidation of lipids in foodstuffs results in the development of off-flavors, resulting in a product that is unacceptable for human consumption (Fernandez et al., 1997). Besides the anti-oxidant activity of ginger, it also displays anti-microbial activities. It is worthy of note that the antiseptic potential of spices like ginger resides in the essential oils (Verluyten, 2004).

There has been an increase in consumer awareness regarding the use of chemical additives in food and food products (Tiwari et al., 2009; Kurkubic et al., 2014; Chaves Lopez et al., 2015). This has resulted in an increase in research on new and unique spice flavorings that will meet the rising global demand for authentic ethnic and cross-cultural cuisines. Consumers are also in quest of natural foods and natural preservatives for healthier lifestyles and natural ways of preventing ailments. 


\section{Quality characteristics of beef sausage containing of ginger (Zingiber officinale) powder}

(Philips et al., 1993; Slattery et al., 2000; Karre et al., 2013). To this end, spices like ginger are being sought for their medicinal value, as anti-oxidants and as antimicrobial. Ginger has been widely used as a dietary spice, as well as in traditional oriental medicine (Surh et al., 1999). There is little or no knowledge about the acceptable levels if included in fresh sausages production, hence this study.

\section{Materials and methods}

The experiment was carried out in the Meat Processing Laboratory of the Department of Animal Production and Health, Federal University of Agriculture, Abeokuta, Ogun state.

The equipment used were Kenwood (Hampshire UK) mincing machine, water bath, artificial casings, bowls, plates and knife.

\section{Processing of ginger}

The rhizomes of ginger (Zingiber officinale) were procured, washed with water and chopped into tiny pieces of about $0.5 \mathrm{~cm}$ diameter. These were sun-dried for 3 days, until constant weight was attained and milled into fine powder using a mechanical grinder. Proximate analysis was also noted to determine the moisture, protein, fats, carbohydrate contents as well as ash and fibre values of the rhizome using the method described by AOAC (2005).

\section{Preparation of beef sausage}

Fresh beef was bought from a healthy source. It was washed, weighed and cut into smaller. A $1 \mathrm{~kg}$ batch of beef sausage for each treatment was produced. The meat was divided into 5 treatments, with each weighing $500 \mathrm{~g}$. The measured and prepared meat was then run through a $5 \mathrm{~mm}$ plate in a Kenwood (Hampshire UK) mincing machine. Similar amounts of beef, wheat flour, oil and water were added to each batch of the beef sausages. Only the seasoning was varied as follows; Batch 1 was the Control ( $0 \%$ Ginger powder), Batch 2 had $25 \%$ of the seasoning as Ginger powder, Batch 3 had $50 \%$ of the seasoning as Ginger powder of total seasoning), Batch 4 had $75 \%$ of the seasoning as Ginger powder and Batch 5 had $100 \%$ of the seasoning as Ginger. See table 1.

Table 1: Recipe (\%) of beef sausage

\begin{tabular}{cccccc}
\hline & \multicolumn{5}{c}{ Batches } \\
\cline { 2 - 6 } Ingredients (\%) & $\mathbf{1}$ & $\mathbf{2}$ & $\mathbf{3}$ & $\mathbf{4}$ & $\mathbf{5}$ \\
\hline Beef & 50.00 & 50.00 & 50.00 & 50.00 & 50.00 \\
Wheat flour & 25.00 & 25.00 & 25.00 & 25.00 & 25.00 \\
Oil & 10.00 & 10.00 & 10.00 & 10.00 & 10.00 \\
Water & 13.00 & 13.00 & 13.00 & 13.00 & 13.00 \\
* Seasoning & 2.00 & 1.50 & 1.00 & 0.50 & 0.00 \\
Ginger & 0.00 & 0.50 & 1.00 & 1.50 & 2.00 \\
Total & $\mathbf{1 0 0}$ & $\mathbf{1 0 0}$ & $\mathbf{1 0 0}$ & $\mathbf{1 0 0}$ & $\mathbf{1 0 0}$ \\
\hline
\end{tabular}

Determination of refrigeration weight loss

Replicated treatment samples of uncooked beef sausages were labelled and weighed prior to refrigeration. The weight of each replicate in each treatment was taken after 24 hours of refrigeration at $2^{\circ} \mathrm{C}$.
Refrigeration loss was the difference between the pre and post-refrigeration weights of the samples as shown;

Refrigeration loss $(g)=$ weight of samples before refrigeration weight of sample after refrigeration 
Refrigerated loss $(\%)=$ weight before refrigeration- weight after refrigeration $\quad x \quad 100$ Weight before refrigeration

Determination of cooking losses and changes in thickness

Treatment samples of beef sausage with 3 replicates in each treatment were prepared alike. Artificial casing stuffed with each sample and sealed at both ends to prevent leakage of the content, in the artificial casing. The initial weight of each sample replicated in each treatment was recorded, before pan frying for 15 minutes. Internal temperature attained for cooked sausage was $80^{\circ} \mathrm{C}$. Final weights and change in weights of cooked sausages was calculated as follows;

Cooking loss $(g)=$ Weight before frying $(g)$

- Weight after frying (g)

Cooking loss $(\%)=\underline{\text { Weight before frying - }}$ Weight after frying $x 100$

Weight before frying

\section{Sensory Evaluation}

A brief group session was held to orient the panelists. Sensory evaluation of samples of fried beef sausages was assessed by seven (7) panelists. Bite size portion of three replicates in each treatment was served at room temperature to panelists who were asked to comment freely on each sample served. Each panelist was required to masticate one sample per treatment with ranked preferences in the following categories: colour, juiciness, meaty flavour, tenderness, saltiness, overall flavour and overall acceptability and then awarded scores using a 9-point Hedonic scale Hedonic $(1=$ Dislike extremely, $2=$ Dislike very much, $3=$ Dislike moderately, $4=$ Dislike slightly, $5=$ Intermediate, $6=$ Like slightly, $7=$ Like moderately, $8=$ Like very much, 9 =Like extremely). Cross et al. (1975)

\section{Proximate analysis}

Proximate composition of beef sausages was determined. Parameters evaluated include dry matter, crude protein, ether extract, ash using the procedure outlined by AOAC, 1995.

\section{Statistical Analysis}

All data generated in this study was subjected to one-way analysis of variance in a completely randomized design using the statistical package (SPSS, 1999) while significant differences were separated using Duncan Multiple Range Test at 5\% level of significance.

\section{Results}

Table 2 shows that all the parameters were significantly $(\mathrm{P}<0.05)$ different amongst the various treatment batches. Although, refrigerated weight losses were all less than $5 \%$, the control batch of $0 \%$ level of Ginger powder inclusion recorded highest $(\mathrm{P}<0.05)$ weight losses of $3.10 \%$ while batch 2 sausages with $0.5 \%$ level (25\%) of Ginger powder inclusion recorded the lowest value $(0.73 \%)$.

Table 2: Effect of varying levels of Ginger powder inclusion on refrigeration weight loss of beef sausage

\begin{tabular}{|c|c|c|c|c|c|c|}
\hline \multicolumn{7}{|c|}{ Batches } \\
\hline Parameter & $\begin{array}{c}1 \\
(0 \% G P)\end{array}$ & $\begin{array}{c}2 \\
(0.5 \% G P)\end{array}$ & $\begin{array}{c}3 \\
(1.0 \% G P)\end{array}$ & $\begin{array}{c}4 \\
(1.5 \% G P)\end{array}$ & $\begin{array}{c}5 \\
(2.0 \% \text { GP })\end{array}$ & SEM \\
\hline Initial weight $(\mathrm{g})$ & 50.00 & 50.00 & 50.00 & 50.00 & 50.00 & 0.00 \\
\hline Final weight $(\mathrm{g})$ & $48.45^{\mathrm{c}}$ & $49.63^{\mathrm{a}}$ & $48.36^{\mathrm{c}}$ & $48.68^{\mathrm{bc}}$ & $49.06^{\mathrm{b}}$ & 0.14 \\
\hline Weight loss (g) & $1.55^{\mathrm{a}}$ & $0.37^{\mathrm{c}}$ & $1.64^{\mathrm{a}}$ & $1.32^{\mathrm{ab}}$ & $0.94^{\mathrm{b}}$ & 0.14 \\
\hline Weight loss $(\%)$ & $3.10^{\mathrm{a}}$ & $0.73^{\mathrm{c}}$ & $3.28^{\mathrm{a}}$ & $2.64^{\mathrm{ab}}$ & $1.88^{\mathrm{b}}$ & 0.28 \\
\hline
\end{tabular}

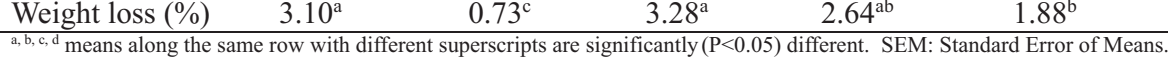




\section{Quality characteristics of beef sausage containing of ginger (Zingiber officinale) powder}

Table 3: Effect of varying levels of Ginger powder inclusion on cooking weight loss of beef sausage

\begin{tabular}{|c|c|c|c|c|c|c|}
\hline \multicolumn{7}{|c|}{ Batches } \\
\hline Parameters & $\begin{array}{c}1 \\
(0 \% \text { GP })\end{array}$ & $\begin{array}{c}2 \\
(0.5 \% G P)\end{array}$ & $\begin{array}{c}3 \\
(1.0 \% G P)\end{array}$ & $\begin{array}{c}4 \\
(1.5 \% G P)\end{array}$ & $\begin{array}{c}5 \\
(2.0 \% G P)\end{array}$ & SEM \\
\hline Initial weight (g) & 50.00 & 50.00 & 50.00 & 50.00 & 50.00 & 0.00 \\
\hline Final weight (g) & $45.50^{\mathrm{a}}$ & $43.73^{\mathrm{ab}}$ & $42.16^{\mathrm{b}}$ & $43.60^{\mathrm{ab}}$ & $43.95^{\mathrm{ab}}$ & 0.44 \\
\hline Weight loss (g) & $4.50^{\mathrm{b}}$ & $6.27^{\mathrm{ab}}$ & $7.84^{\mathrm{a}}$ & $6.40^{\mathrm{ab}}$ & $6.05^{\mathrm{ab}}$ & 0.44 \\
\hline Weight loss $(\%)$ & $9.01^{\mathrm{b}}$ & $12.55^{\mathrm{ab}}$ & $15.68^{\mathrm{a}}$ & $12.81^{\mathrm{ab}}$ & $12.11^{\mathrm{ab}}$ & 0.88 \\
\hline
\end{tabular}

Table 3 also shows significant differences $(\mathrm{P}<0.05)$ in all the parameters measured in cooking weight losses of beef sausage, as affected by varying levels of Ginger powder inclusion. Although no particular pattern of cook loss was followed, final weight of the sausage samples was significantly different $(\mathrm{P}<0.05)$ among the treatment batches with the lowest weight of $9.01 \%$ recorded for $0 \%$ level of Ginger powder inclusion. However, the highest weight loss $(15.68 \%)$ was recorded in batch 3 sausage.

All parameters evaluated for sensory characteristics were not significantly different $(\mathrm{P}>0.05)$ except meaty flavour which was significantly different $(\mathrm{P}<0.05)$ as shown in Table 4 . Batch 1 with $0 \%$ Ginger powder inclusion level had the highest score for meaty flavour with a score of 6.50 which indicates slightly meaty while batch 2 sausages with $0.5 \%$ (25\%) Ginger powder inclusion level had the lowest score of 4.00 .

Table 5 shows the effect of Ginger powder inclusion at varying levels on Proximate Composition of beef sausage. There was significant difference $(\mathrm{P}<0.05)$ in all the parameters measured among the treatment batches of sausages produced.

The lowest value for Crude protein was recorded in batch 1 (control) with a value of $18.40 \%$, all other treatment groups $(2,3,4$ and 5) had statistically similar values of $25.52 \%, 22.03 \%, 24.06 \%$ and $26.66 \%$ respectively. Ether extract was higher $(\mathrm{P}<005)$ in Ginger powder sausages than $0 \%$ ginger Sausage.

Table 4: Sensory Properties of Beef Sausage produced with Ginger inclusion at varying levels

\begin{tabular}{|c|c|c|c|c|c|c|}
\hline \multirow[b]{2}{*}{ Parameters } & \multirow[b]{2}{*}{$\begin{array}{l}1 \\
(0 \% \text { GP) }\end{array}$} & \multicolumn{3}{|l|}{ Batches } & \multirow[b]{2}{*}{$\begin{array}{l}5 \\
(2.0 \% G P)\end{array}$} & \multirow[b]{2}{*}{ SEM } \\
\hline & & $\begin{array}{l}2 \\
(0.5 \% G P)\end{array}$ & $\begin{array}{l}3 \\
(1.0 \% G P)\end{array}$ & $\begin{array}{l}4 \\
(1.5 \% G P)\end{array}$ & & \\
\hline Colour & 5.50 & 5.50 & 4.50 & 5.00 & 5.00 & 0.57 \\
\hline Juiciness & 4.50 & 4.00 & 4.50 & 4.50 & 5.00 & 0.71 \\
\hline Meaty Flavour & $6.50^{\mathrm{a}}$ & $4.00^{c}$ & $5.00^{\mathrm{bc}}$ & $4.50^{\mathrm{bc}}$ & $5.50^{\mathrm{ab}}$ & 0.99 \\
\hline Tenderness & 6.00 & 5.50 & 5.00 & 4.00 & 6.00 & 1.06 \\
\hline Saltiness & 4.50 & 4.50 & 4.50 & 4.00 & 4.50 & 0.52 \\
\hline Overall Flavour & 6.00 & 4.50 & 5.00 & 5.00 & 5.00 & 0.74 \\
\hline Overall Acceptability & 6.00 & 5.00 & 5.00 & 5.00 & 5.00 & 0.79 \\
\hline
\end{tabular}

Table 5: Effect of Ginger powder inclusion at varying levels on Proximate Composition of Beef Sausage

\begin{tabular}{lllllll}
\hline & \multicolumn{5}{c}{ Batches } \\
Parameters & $\mathbf{1}$ & $\mathbf{2}$ & $\mathbf{3}$ & $\mathbf{4}$ & $\mathbf{5}$ & SEM \\
& $\mathbf{( 0 \%} \mathbf{G P})$ & $\mathbf{( 0 . 5 \% G P )}$ & $\mathbf{( 1 . 0 \% G P )}$ & $\mathbf{( 1 . 5 \% G P )}$ & $\mathbf{( 2 . 0 \% G P )}$ & \\
\hline Dry Matter (\%) & $67.75^{\mathrm{a}}$ & $67.25^{\mathrm{ab}}$ & $67.50^{\mathrm{a}}$ & $67.50^{\mathrm{a}}$ & $66.75^{\mathrm{b}}$ & 0.13 \\
Crude Protein (\%) & $18.40^{\mathrm{b}}$ & $25.52^{\mathrm{a}}$ & $22.03^{\mathrm{a}}$ & $24.06^{\mathrm{a}}$ & $26.66^{\mathrm{a}}$ & 1.74 \\
Ash (\%) & $3.75^{\mathrm{a}}$ & $3.50^{\mathrm{ab}}$ & $3.75^{\mathrm{a}}$ & $3.25^{\mathrm{b}}$ & $3.00^{\mathrm{b}}$ & 0.12 \\
Ether (\%) & $20.00^{\mathrm{b}}$ & $22.00^{\mathrm{b}}$ & $21.00^{\mathrm{b}}$ & $21.00^{\mathrm{b}}$ & $31.00^{\mathrm{a}}$ & 1.04 \\
\hline a,b, means along the same row with different superscripts are significantly $(\mathrm{P}<0.05)$ different. SEM: Standard Error of Means
\end{tabular}




\section{Discussion}

The values recorded for refrigerated weight losses were all within the range of $1-10 \%$ refrigerated weight loss. This could be attributed to gingerol, which is natural oil in ginger as oils are known to help in binding. This observation was corroborated by Lamya et al. (2012) who reported that ginger powder inclusion at varying levels favoured the product's resistance to diffusion, thus maintaining storage stability. However, this was observed to be contrary for the pan fried sausages which gave higher cook loss values in all the sausage batches having Ginger powder included at varying levels except for Batch 1 with $0 \%$ Ginger powder inclusion level. This findings was also contrary to the report of Sheard et al. (1998) that sausages with less fat loose more of its water content regardless of the cooking method adopted than the more oil containing sausages as well as Naveena and Mendiratta (2001) that Ginger extract treatment increased the $\mathrm{pH}$, moisture, cooking yield, total pigments, water holding capacity, collagen solubility, protein extractability, muscle fibre diameter and decreased the share force values of meat and meat products.

Meaty flavour was the only sensory evaluation affected by ginger inclusion. This observation was contrary to reports by Lee et al. (1986) that tenderness in meat was improved by an addition of ginger at $30 \%$ inclusion of the seasoning. According to the authors, ginger rhizome protease is an effective meat tenderizer and the tenderization is achieved through preferential degradation of thin filaments and that tenderness improved with the addition of Ginger extract according to Naveena and Mendiratta (2001).

In Table 5, the highest value of crude protein was recorded in Batch 5 which had $100 \%$ (Ginger powder) inclusion of the total seasoning. This result agreed with the report of Pil-Nam Seong et al. (2016) who replaced $1 \%$ of ground garlic to total seasoning in fermented sausage production and had a higher crude protein value of $23.34 \%$ when compared with sausages with no added spice.

\section{Conclusion}

The inclusion of ginger (Zingiber officinale) as a seasoning up to $100 \%$ improved refrigeration stability and had no consumer bias on sensory characteristics. The use of ginger in sausage production did not reduce cooking loss. However, if nutrient composition is to be considered, inclusion of $0.5 \%$ ginger powder $(25 \%)$ will help improve crude protein in sausage.

\section{References}

AOAC (Association of Official Analytical Chemists) 2005. Official Methods ofAnalysis. $18^{\text {th }}$ edition. AOAC. International, Arlington V. A, USA; pp. 30-31(Chapter 4)).

Chaves - Lopez C. Serio, A. Mazzarrino, G. Paparella, A. 2015. Control of house hold mycoflora in fermented sausages using phenolic fractions from olive mill waste water. Int. $J$. Food Microbiol. 207: 49-56.

Fernandez, J., Perej-Alvarez, J. A. and Fernadez-Lopez, J. A. 1997. Thiobarituric acid test for monitoring lipid oxidation in meat. Food chemistry, 59(3): 345-353.

Karre, L., Lopez, K. and Getty, J. K. 2013. Natural anti-oxidants in meat and poultry products. Meat sci., 94:220 227.

Kurcubic, V. S. Maskovic, P. Z, Vujic, J. M. Vranic, D. V. VeskovicMoracanin, S. M. Okanovic, D. G. and Lilic, S. 2014. Anti oxidants anti microbial activity of Kitaibelia 
Vitifolia extract as alternative to the added nitrite in fermented dry sausage. Meat Sci. 97: 459-457.

Lamya, El Sediek, Wafaa, M. M. Abozeid, Dalal H .Alkhalifah, and Serag, E. A. Farag., 2012. Efficacy of ginger extract (Zingiber officinale ) and gamma irradiation for quality and shelf-stability of processed frozen beef sausage. Life Science Journal, 9(2):448-461. ( I S S N : 1097 - 8135 ). http://www.lifesciencesite.com

Lee, Y. B., Sehnert, D. J. and Ashmore, C. R. 1986. Antioxidant property in ginger rhizome and its applications to meat products. J. Food Sci. 51: 20-23.

Merinoff, L. 2007. The savory sausage : A culinary tour around the world. New York : Poseidon Wikipedia (2007). Report by the World Cancer Research Fund.

Philips, R. W., Kikendall, J. W., Luk, G. D., Willis, S. M., Murphy, J. R. and Maydonovitch. 1993. Carotene inhibits rectal mucosal ornithine decarboxylase activity in colon ancer patients. Cancer Res. 53:3723-3725.

Pil-Nam, S., Hyun-Woo, S., Sun- Moon, K., Yoon-Seok, K., Soo-Hyun, C., Jin- Hyoung, $K$. and Van-Ba, $H$. 2016. Beneficial effect of traditional seasonings on quality characteristics of fermented sausages. Asian- Austrailer Asian Journal of Animal Science. 29(8): $1173-180$.
Naveena, B. M. and Mendiratta, S. K., 2001. Tenderisation of spent hen meat using ginger extract. British Poultry Science, 42: 344-349.

Sheard, P. R, Nute, G. R, and Chappell, A. G. 1998. The effect of cooking on the chemical composition of meat products with special references to fat loss. Meat science, 49(2); 175 191.

Slattery, M. L. Benson. J. Curtin, K. Ma, K. N. Schaeffer, D. and Potter, J. D. 2000. Carotenoids and Colon cancer 1. Am. J. Clin.. Nutri. 71: 575 -582 .

Surh, Y. J., Park, K. K., Chun, K. S., Lee, L. J., Lee, E. and Lee, S. S. 1999. Anti-tumor-promoting activities of selected pungent phenolic substances present in ginger. College of Pharmacy, Seoul National University, Seoul, South Korea. J Environ Pathol Toxicol Oncol 18(2):131-9.

Tiwari, B. K., Valdramidis, V. P., $\mathbf{O}^{\prime}$ D o n n e l l , C . P ., Muthukumarappan, K. Bourke, P. and Cullen, P. J., 2009. Application of natural antimicrobials for food preservation. Journal of Agricultural Food Chemistry, 57:5987-6000.

Received: $7^{\text {th }}$ February, 2017 Accepted: $21^{\text {st }}$ June, 2017 